\title{
Production within the rumen and removal from the blood-stream of volatile fatty acids in sheep given a diet deficient in cobalt
}

\author{
By THE LATE HEDLEY R. MARSTON, SHIRLEY H. ALLEN AND \\ R. M. SMITH \\ Division of Nutritional Biochemistry, ${ }^{*}$ Commonwealth Scientific and \\ Industrial Research Organization, University of Adelaide, \\ South Austral. 5000, Australia
}

(Received I6 April 197I - Accepted 24 June 1971)

I. The production and metabolism of volatile fatty acids were studied in sheep offered a cobalt-deficient diet.

2. The mola1 proportions of acetic $(60 \%)$, propionic $(26 \%)$ and butyric ( $14 \%)$ acids in the rumen fluids of sheep given the Co-deficient diet, but whose stores of vitamin $B_{13}$ were adequate, were similar before and after administration of an oral supplement of $\mathrm{Co}$.

3. In pair-fed sheep, one member of which was vitamin $B_{12}$-deficient and the other (control) treated with vitamin $B_{12}$ patenterally, the concentrations after feeding of both total and individual volatile fatty acids in the blood tended to be higher in deficient than in contro! sheep.

4. Following injection of the respective salts of individual volatile fatty acids into the blood-stream, formate clearance was apparently not affected, whereas that of acetate was slightly, and that of propionate very significantly, delayed in vitamin $B_{12}$-deficient sheep compared with pair-fed control animals.

5. Acetate metabolism was retarded in the presence of propionate; the effect was greater in deficient than in pair-fed control sheep.

6. The hypothesis is advanced that it is the failure to metabolize propionate at the normal rate that leads to the progressive loss of appetite in vitamin $B_{12}$-deficient sheep.

Loss of appetite, the first sign of vitamin $B_{12}$ deficiency seen in sheep that consume a cobalt-deficient diet, occurs when the concentration of vitamin $B_{12}$ in the liver is reduced to about $0.1 \mu \mathrm{g} / \mathrm{g}$ liver tissue (Marston, 1970).

Observation of pair-fed animals showed that, whereas the animal whose stores of vitamin $B_{12}$ were adequate ate the whole of its ration in $I-2 h$, the deficient member of the pair might take $24 \mathrm{~h}$ to consume the same amount of food. Following a $24 \mathrm{~h}$ fast, a deficient sheep sometimes ate ravenously for a short time and then left the remainder of its zation untouched for several hours.

The association, in deficient sheep, between consumption of small quantities of food and impairment of appetite led to a search for a metabolite(s) which accumulated in the blood-stream after feeding. As the ruminant derives the major portion of its energy from volatile fatty acids produced by fermentation, a study was made of some aspects of the production, absorption and utilization of these acids in shecp given the Co-deficient dict. Lack of $\mathrm{Co}$ in the diet had no apparent influence on production or absorption of the volatile fatty acids produced by micro-organisms within the rumen. In those animals in which there was a lack of vitamin $B_{12}$ in the tissues, however, 
retardation in the rate of metabolism of acetate and propionate after feeding, and following their intravenous injection, usually occurred. These observations led us to suggest that the primary metabolic lesion responsible for loss of appetite in vitamin $\mathrm{B}_{12}$-deficient sheep is a failure to metabolize propionate at a normal rate.

EXPERIMENTAL

Animals. Fifty-two Merino ewes, 2-5 years old, were given a standard Co-deficient diet (Smith \& Marston, I970 b). The full ration of I $\mathrm{kg} \mathrm{Co-deficient} \mathrm{wheaten} \mathrm{hay}$ chaff $+50 \mathrm{~g}$ wheat gluten supplied about $4000 \mathrm{kcal}$ and $\mathbf{1} 7 \mathrm{~g}$ nitrogen.

Pairs of sheep were chosen on the basis of similarity in age, food intake and bodyweight. One member of the pair (control) was treated throughout the period of observation with either $50 \mu \mathrm{g}$ vitamin $\mathrm{B}_{12} / \mathrm{d}$ or $250 \mu \mathrm{g} /$ week by intramuscular injection and its food intake was restricted to that consumed on the previous day by the deficient member of the pair.

Rumen fluid. Samples of rumen fluid were obtained as described by Smith \& Marston (1970a).

Injection of acids. As the sheep's renal threshold for volatile fatty acids is relatively high, the procedure adopted throughout these observations was to inject the sodium salts of the acids, $3.5 \mathrm{mmol} / \mathrm{kg}$ body-weight, via a fine polyethylene tube implanted temporarily into an external jugular vein. The acids were neutralized with $\mathrm{NaOH}$, diluted to a molar solution, heated to $38^{\circ}$ and injected steadily over a period of $5 \mathrm{~min}$, Blood samples $(5 \mathrm{ml})$ were collected through the tube before and usually $3,15,30$, 45 and $60 \mathrm{~min}$ after the injection; and thereafter, for deficient sheep, at $30 \mathrm{~min}$ intervals over the next $\mathrm{I}-\mathbf{2} \cdot 5 \mathrm{~h}$, and for control sheep at intervals until the concentration of total volatile fatty acids in the blood-stream had returned to that beforc injection. After each operation the volume of blood withdrawn was replaced with physiological saline and the tube was filled with a solution of heparin $(40 \mathrm{i} . \mathrm{u} . / \mathrm{ml}$ physiological saline).

Unless otherwise stated, the animals were fasted for i $8 \mathrm{~h}$ before injection of the acids but had access to water at all times.

Estimation of volatile fatty acids. Samples of rumen fluid and of tungstic acid filtrates of blood were distilled at constant volume $(20 \mathrm{ml})$ after addition of $10 \mathrm{~g}$ $\mathrm{MgSO} .{ }_{7} \mathrm{H}_{2} \mathrm{O}$ and sufficient $\mathrm{H}_{3} \mathrm{PO}_{4}$ to make the solution acid to Congo red paper; $100 \mathrm{ml}$ distillate were collected. Portions of distillate were titrated with $\mathrm{NaOH}$ under nitrogen gas to $\mathrm{pH} 7 \cdot \circ$ (glass electrode).

The relative proportions of individual volatile fatty acids were determined by gasliquid chromatography (James \& Martin, 1952), using the micro-column described by Annison (1954) for transfer of the acids to the main column. Anhydrous magnesium sulphate was found to be a more satisfactory dehydrating agent in the microcolumn than anhydrous sodium sulphate. The small proportion, about $3 \%$, of volatile acids other than acetic, propionic and butyric found in rumen fluid and the not more than $3 \%$ of volatile acids other than formic, acetic and propionic found in blood have been neglected in computing the ratios reported. 


\section{RESULTS}

\section{Influence of Co on ruminal volatile fatty acids}

Rumen fluid was obtained via fistulas (Jarrett, I948) from ewes 1 Io and 193 during periods when the animals were being treated with Co per os and after withdrawal of treatment. Both animals consumed the major portion of their daily ration ( $105 \circ \mathrm{g}$ ) within $4 \mathrm{~h}$ of its being offered and both animals had adequate stores of vitamin $\mathrm{B}_{12}$ for their full physiological needs. Over the period o- $8 \mathrm{~h}$ after feeding, the molar propor-
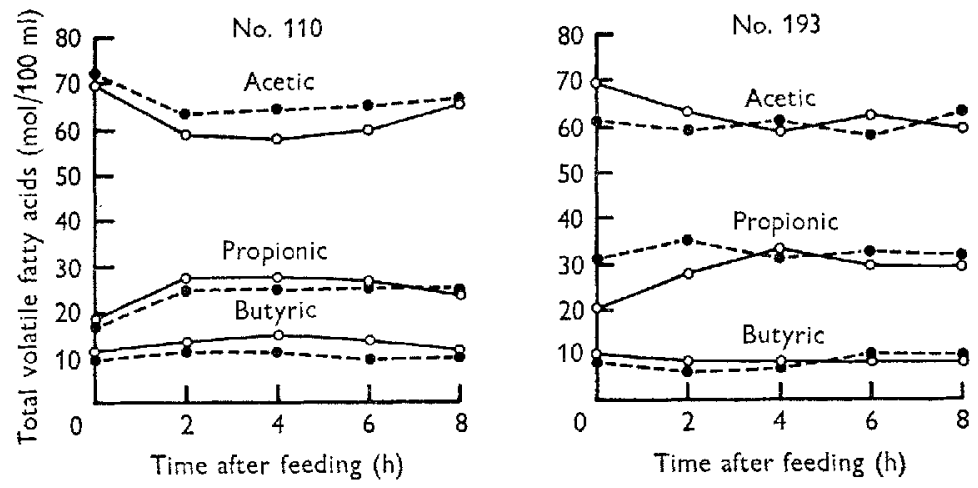

Fig. I. Relative molar proportions of acetic, propionic and butyric acids in rumen contents of sheep $\mathrm{I}$ IO and I 93 over the period $a-8 \mathrm{~h}$ after the Co-deficient ration was offered. --0 , Co-sufficient rumen (Co+), sheep treated with I $\mathrm{mg} \mathrm{Co} / \mathrm{d}$ per os; $\mathrm{O}-\mathrm{O}$, Co-deficient rumen $(\mathrm{Co}-)$.

tions of acetic, propionic and butyric acids did not vary greatly and were independent of the Co concentration in the rumen within the limits of 6-8o ng Co/g rumen contents (Fig. I). Treatments were as follows: ewe I IO: Co, I mg/d per os, was administered for $16 \mathrm{~d}$ before samples were withdrawn from its Co-sufficient rumen ( $\mathrm{Co}+$; about $80 \mathrm{ng}$ Co/g rumen contents) and treatment with Co ceased $\mathrm{I}_{4}$ weeks before sampling of its Co-deficient rumen ( $\mathrm{Co}-$; about $6 \mathrm{ng} \mathrm{Co} / \mathrm{g}$ rumen contents). The corresponding times for ewe 193 were $7 \mathrm{I}$ weeks $(\mathrm{Co}+)$ and $\mathrm{r} 6 \mathrm{~d}(\mathrm{Co}-)$. The concentration of $\mathrm{Co}$ in the rumen of a sheep is reduced to that dictated by the Co content of the diet within $5 \mathrm{~d}$ of cessation of treatment with Co (Smith \& Marston, r970a).

Additional evidence for the apparent lack of effect of Co concentration in rumen contents on the molar proportions of volatile fatty acids was provided by the remarkably constant ratio of these acids found in samples obtained from the rumen of ewe I IO, $4 \mathrm{~h}$ after feeding, on the day before and on days $\mathrm{I}-5$ inclusive and $7,14,2 \mathrm{I}$, 28 and 98 after cessation of treatment with Co. The mean molar proportions and standard deviations of a single observation of the eleven samples were: acetic $59.5 \%$, $\mathrm{I} \cdot 2 \%$; propionic $26 \cdot 2 \%, \mathrm{I} \cdot 0 \%$; butyric $14.4 \%, \mathrm{I} \cdot \mathrm{O} \%$.

\section{Concentrations of volatile fatty acids in blood after feeding}

After feeding, the concentrations in blood of total volatile fatty acids and of formic, acetic and propionic acids in both vitamin $B_{12}$-deficient and control sheep varied over 
a relatively wide range; usually, however, they were higher in the deficient animal. Mean concentrations together with the degrees of significance of the results for seven pairs of sheep, $4 \mathrm{~h}$ after food was offered, are reported in Table I.

Table I. Concentrations of volatile fatty acids (VFA) in blood samples of seven pairs of sheep 4 h after food was offered (means and standard deviations of means)

\begin{tabular}{|c|c|c|c|}
\hline Acid & $\begin{array}{c}B_{12} \text {-deficient } \\
(\mathrm{mmol} / 1)\end{array}$ & $\begin{array}{l}\mathrm{B}_{12} \text {-sufficient } \\
(\mathrm{mmol} / \mathrm{l})\end{array}$ & $P$ \\
\hline Total VFA & $2 \cdot 7,0.69$ & O.90, O'I5 & $<0.05$ ( $d$ test $)$ \\
\hline Formic & $0.18,0.039$ & $0.11,0.039$ & $\mathrm{NS}(t$ test $)$ \\
\hline Acetic & $2 \cdot 2,0.65$ & $0.75,0.13$ & $\mathrm{NS}$ ( $d$ test) \\
\hline Propionic & $0.27,0.060$ & $0.04,0.01$ & $<0.0 \mathrm{I}(d$ test $)$ \\
\hline
\end{tabular}

\section{Remowal of volatile fatty acids from the blood}

Partition, by gas-liquid chromatography, of the acids present in the blood-stream after injection of an individual acid showed that the proportions of other acids were so small that they could be neglected. Concentrations for clearance tests are therefore reported as those of the acid injected, whereas, in fact, concentrations of total volatile fatty acids were estimated.

Regressions of the concentration in the blood of the injected acid on time were determined for each clearance test. The dependent variate was the logarithm of the concentration of acid in $\mathrm{mmol} / \mathrm{l}$ blood, and time in min was the independent variate. To conform with convention, the regression coefficients have been multiplied by $-2 \cdot 30259$ to give rate-constants. The relationship of these constants to food intake, measured as the mean daily intake over the $7 \mathrm{~d}$ preceding the test, was determined for acetate and propionate.

Formate. The rate at which the concentration of formate in the blood fell following its intravenous injection was not, in the four pairs of determinations made, significantly different in deficient and control sheep. In two of the pairs food was removed from the vitamin $B_{12}$-deficient animal i $8 \mathrm{~h}$ before, and in the other two immediately before, the test. Consumption of food before the test did not seem to influence the results, which therefore have been treated as four observations on four deficient sheep.

Rate-constants were determined for each of eight formate clearance tests. The means for the vitamin $B_{12}$-deficient and control sheep were, respectively, 0.00643 and $0.0089 \mathrm{I}$ (SD of difference of the means $0.00 \mathrm{I} 22$ ) and were not significantly different by the $t$ test.

Acetate. The rate at which acetatc disappeared from the blood-stream following its intravenous injection was just significantly lower $(P<0.05$ by the $d$ test $)$ in vitamin $B_{12}$-deficient sheep than in their controls (Table 2).

The rate of change of concentration of acetate in blood was determined for each of twenty-six acetate-clearance tests on twelve pair-fed sheep and two single deficient animals. Where repeat determinations were made on any pair, means were used in the test of significance. The variances of the individual regression coefficients were heterogeneous owing to heterogeneity among the residual variances of the several 
regression analyses and the variation of the sums of squares of the independent variate. Due allowance was made for this by weighting the regressions inversely as their variances. The wcighted means of the regression coefficients are reported in Table 2 as rate-constants.

The above tests relate to sheep whose daily food intakes ranged from 185 to $560 \mathrm{~g}$; over this range there was no correlation, for either deficient or control animals, between the rate at which acetate was removed from the blood-stream and food intake.

\section{Table 2. Rate-constants of clearance of acetate injected intravenously into sheep} (weighted means and standard deviations of weighted means)

\begin{tabular}{|c|c|c|c|}
\hline Treatment & $\begin{array}{l}\mathrm{B}_{12} \text {-deficient } \\
\left(\mathrm{min}^{-1}\right)\end{array}$ & $\begin{array}{l}\mathrm{B}_{12^{- \text {sufficient }}} \\
\left(\mathrm{min}^{-1}\right)\end{array}$ & $P$ \\
\hline $\begin{array}{l}\text { Starved } \\
\text { Not staryed }\end{array}$ & $\begin{array}{l}0.0266,0.00148(8) \\
0.00780 .0 .00078(4)\end{array}$ & $0.0411,0.00476(6)$ & $<0.05$ ( $a$ test $)$ \\
\hline $\begin{array}{l}\text { Aminopterin } \\
\text { (starved) }\end{array}$ & $0.0374,0.00186(3)$ & $0.0348,0.0002$ II (4) & $\operatorname{NS}(d$ test) \\
\hline
\end{tabular}

Numbers of observations used in test of significance are given in parentheses; NS, not significant.

Consumption of food before injection of acetate markedly reduced the rate at which it was metabolized by vitamin $\mathrm{B}_{12}$-deficient sheep. The weighted mean rate-constant of four clearance tests on four deficient sheep which had access to food up to the time of the test was $0.0078 \mathrm{I}$, which was significantly less $(P<0.00 \mathrm{I}$ by the $t$ test $)$ than that of deficient sheep which had been starved for $\mathrm{i} 8 \mathrm{~h}$ before the test (Table 2 ).

There was no indication, in the relatively small number of animals observed, of a reduction in the rate at which acetate was metabolized by sheep in which the cffective concentration of pteroylglutamic acid had been reduced, and a partial disturbance of histidine catabolism induced, by administration of aminopterin (Marston \& Allen, 1970). The observations included ten clearance tests on four pair-fed sheep, one each on a single vitamin $\mathrm{B}_{12}$-deficient and a single vitamin $\mathrm{B}_{12}$-treated sheep on a restricted food intake and three on a vitamin $B_{12}$-treated sheep whose food intake was not restricted. The weighted means of the rate-constants are reported in Table 2 . In sheep treated with aminopterin the ability to deal with acetate was not significantly different in deficient and control animals.

Propionate. Following its intravenous injection, the rate of fall of concentration of propionate in the blood was significantly lower in deficient sheep than in control animals.

Rate-constants have been determined for each of forty-one propionate clearance tests, comprising tests on twenty-four pair-fed sheep (five observations on one pair and two on each of three pairs), one single deficient sheep and two vitamin $B_{12}$-treated sheep not on a restricted food intake. As a preliminary to the statistical analysis of these values, replicate observations on the same animal in a given state of deficiency (as measured by food intake) were averaged. This introduced differential weights for the observations, but the differences in weights were so small they could be ignored in the two tests of significance which are described in the next paragraph. 
The average rate-constant of deficicnt sheep $(0.0175$, SD 0.00138 , fifteen observations) was significantly less $(P<0.0$ r by the $d$ test $)$ than that $(0.0626$, SD 0.00343 , sixtcen observations) of the controls. Significant $(P<0.0$ r by the $t$ test) positive linear regressions of rate-constants of propionate clearance on food intake were obtained both for deficient and control sheep if the observations on the two vitamin

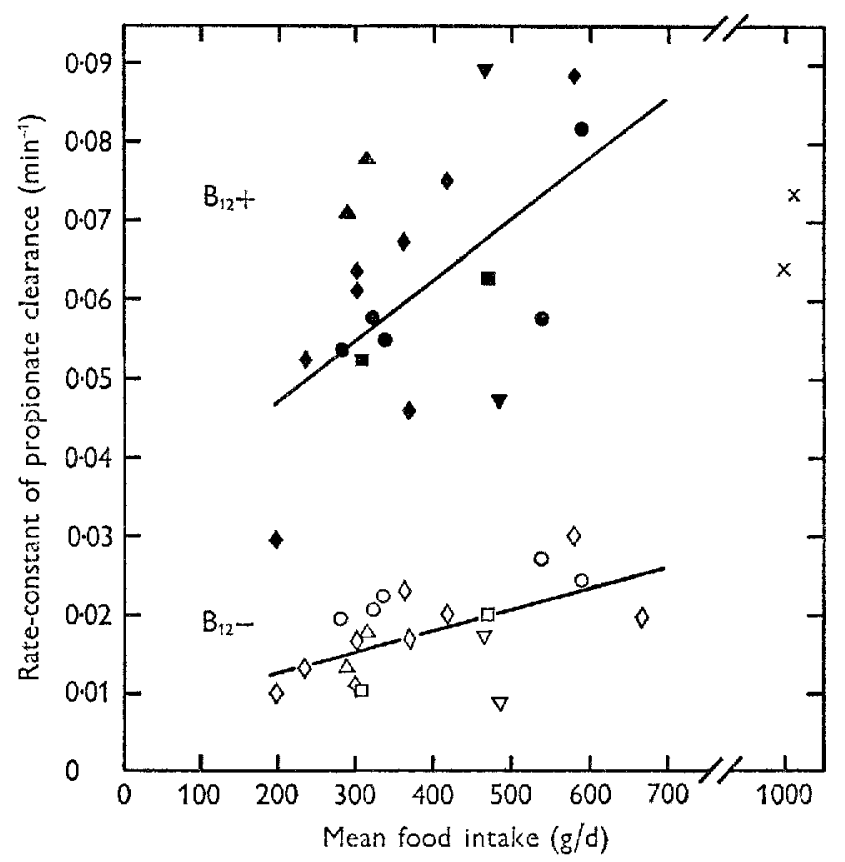

Fig. 2. Regressions of rate-constants of propionate clearance on mean daily food intakes of vitamin $B_{12}$-deficient sheep ( $B_{12}-$, open symbols) and of vitamin $B_{12}$-treated sheep $\left(B_{12}+\right.$, closed symbols and $x$ ). 0 , ewes 109 and $I 0 I$ (five observations on each sheep), means of the three observations at a food intake of about $300 \mathrm{~g} / \mathrm{d}$ and the two observations at more than $500 \mathrm{~g} / \mathrm{d}$ taken respectively; $\square, \mathbf{n}$, ewes I I4 and 282 , two observations on each sheep regarded as independent; $\triangle, \Delta$, ewes 433 and $218 ; \nabla, \nabla$, ewes 100 and 350 , two observations on each sheep of each pair respectively averaged; $\diamond, \diamond$, single observations on pair-fed sheep and individual sheep on restricted food intake; $x$, vitamin $B_{12}$-treated sheep on unrestricted food intake.

$\mathrm{B}_{12}$-sufficient animals, whose food intakes were not restricted, were excluded from the latter (Fig. 2). The regression of the deficient sheep was significantly less $(P<0.05$ by the $d$ test) than that of the controls. As the deficiency worsened and food intake fell the increase in the time taken to metabolize propionate was more pronounced in deficient than in control animals. This is illustrated in Fig. 3, where 'half-times' of propionate clearance are plotted as a function of food intake. 'Half-times' were calculated from the expression

$$
t_{\frac{1}{2}}=\frac{\log _{n}^{2}}{k}=\frac{0 \cdot 693 \mathrm{I} 5}{k}
$$

where $k$ is the rate-constant.

Propionate clearance tests were also made on three vitamin $B_{12}$-deficient sheep and 
on the same sheep $5 \mathrm{~d}$ after intramuscular injection of $800 \mu \mathrm{g}$ vitamin $\mathrm{B}_{12}$. For each animal rate-constants before treatment were significantly less than those after treatment (Table 3).

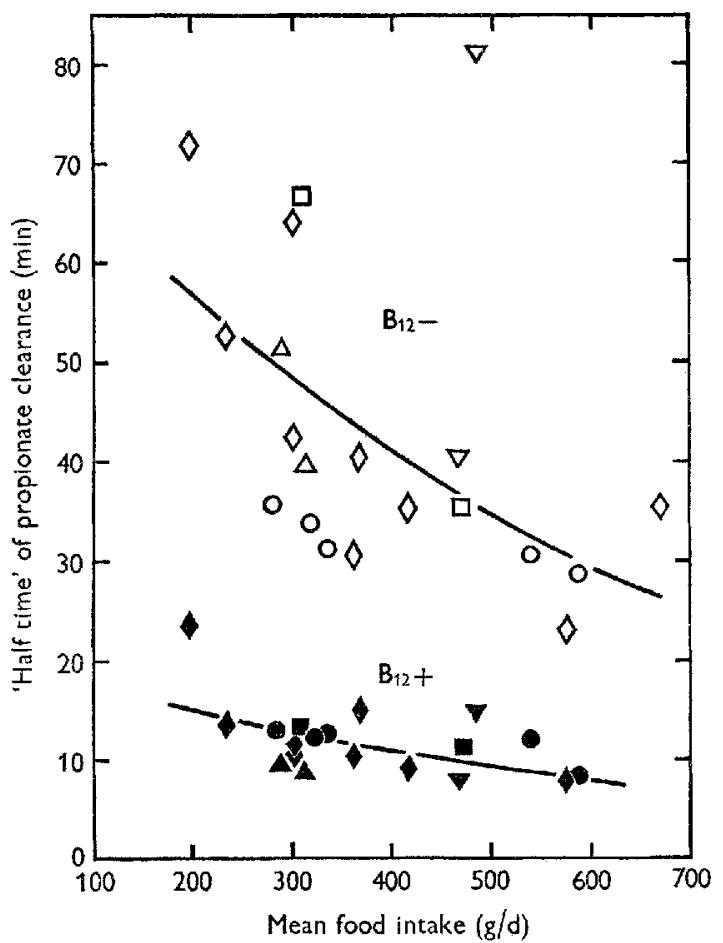

Fig. 3. Relationship between 'half-time' of clearance of propionate, after its intravenous injection, and food intake for vitamin $B_{12}$-deficient $\left(B_{12}-\right)$ and vitamin $B_{12}$-treated $\left(B_{12}+\right)$ sheep. Symbols as in Fig. 2.

Table 3. Rate-constants of clearance of propionate injected intravenously into vitamin $B_{12}$-deficient sheep before $\left(B_{12}-\right)$ and after $\left(B_{12}+\right)$ treatment with vitamin $B_{12}$

(Food intake before treatment was the mean daily intake over the $7 \mathrm{~d}$ before the test; that after treatment was the amount consumed during the $24 \mathrm{~h}$ which ended $24 \mathrm{~h}$ before the test)

\begin{tabular}{|c|c|c|c|c|c|c|}
\hline \multirow{2}{*}{$\begin{array}{ll}\text { Sheep no. } & \ldots \\
\text { Treatment } & \ldots\end{array}$} & \multicolumn{2}{|c|}{$5 \mathrm{I} 8$} & \multicolumn{2}{|c|}{$5^{83}$} & \multicolumn{2}{|c|}{690} \\
\hline & $\mathrm{B}_{12}-$ & $B_{12}+$ & $B_{12}-$ & $\mathbf{B}_{12}+$ & $B_{12}-$ & $\mathrm{B}_{12}+$ \\
\hline $\begin{array}{l}\text { Food intake }(\mathrm{g}) \\
\text { Rate-constant }\left(\mathrm{min}^{-1}\right)\end{array}$ & $\begin{array}{c}578 \\
0.0224\end{array}$ & $\begin{array}{r}1040 \\
0.044 \mathrm{I}\end{array}$ & $\begin{array}{r}292 \\
0.0216\end{array}$ & $\begin{array}{r}630 \\
0.0558\end{array}$ & $\begin{array}{c}304 \\
0.017^{8}\end{array}$ & $\begin{array}{c}674 \\
0.0419\end{array}$ \\
\hline SD & $0.001_{3} 8$ & 0.00622 & $0.00092,1$ & 0.00507 & $0.0013^{8}$ & 0.0018 \\
\hline$P$ & \multicolumn{2}{|c|}{$<0.05(d$ test $)$} & \multicolumn{2}{|c|}{$<0.01(d$ test $)$} & \multicolumn{2}{|c|}{$<0.001$ ( $t$ test $)$} \\
\hline
\end{tabular}

\section{Inhibition of acetate clearance by propionate}

A mixture of acetic and propionic acids, $0.5 \mathrm{M}$ with respect to each, was injected into the sheep under investigation at the rate, for each acid, of $I^{\prime} 75 \mathrm{mmol} / \mathrm{kg}$ bodyweight; as a control, $0.5 \mathrm{M}$ solutions ( $1.75 \mathrm{mmol} / \mathrm{kg}$ ) of each of the acids were injected separately on separate days. The blood filtrates obtained after injection of the mixed 
acids were partitioned by gas-liquid chromatography and the relative proportions of each acid were estimated.

In starved sheep the presence of acetate had little effect on the rate at which propionate disappeared from the blood (Fig. $4 a, b$ ); the metabolism of acetate was, however, retarded in the presence of an approximately equal concentration of propionate (Fig. $4 c, d$ ). The effect was more pronounced in deficient than in control sheep.
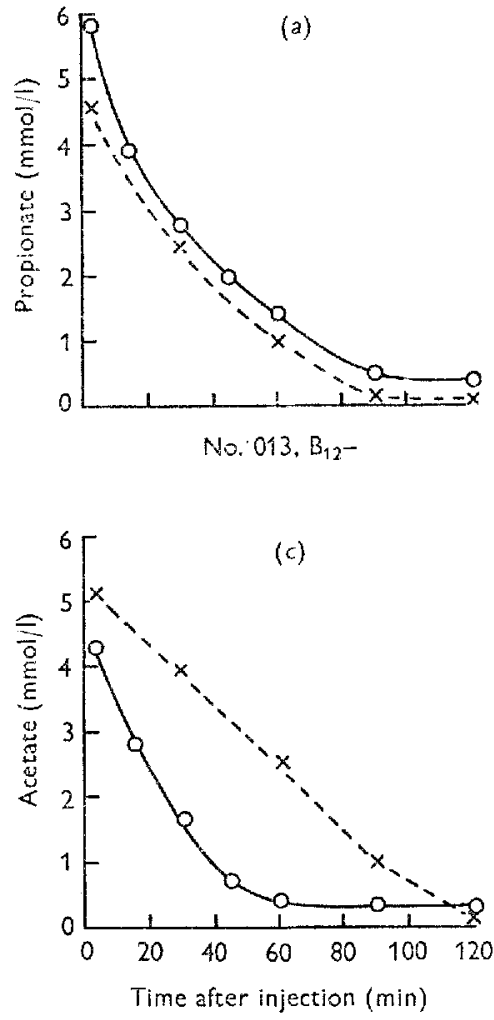

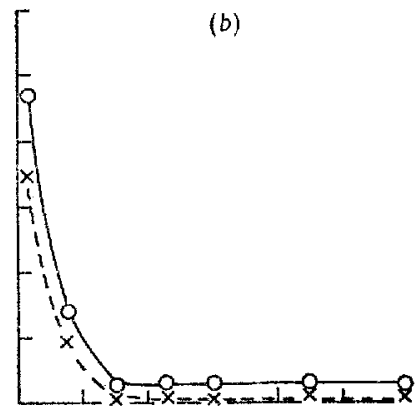

No. $284, B_{12}+$

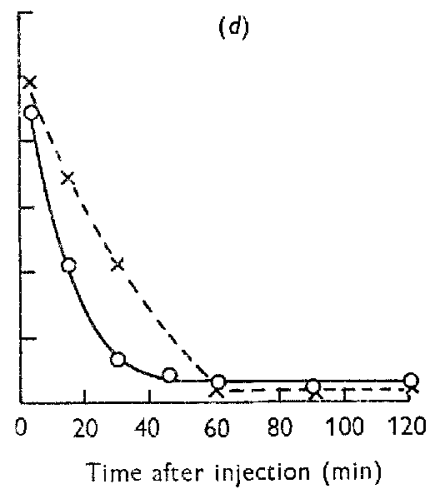

Fig. 4. Rates of removal of injected acetic and propionic acids from the blood of pair-fed vitamin $B_{12}$-deficicnt $\left(B_{12}-\right)$ and control $\left(B_{12}+\right)$ sheep. Ewe or $3\left(B_{12}-\right)$ and ewe $284\left(B_{12}+\right)$ (mean daily food intake $340 \mathrm{~g}$ ) were injected on separate days with acetic acid, propionic acid, and an equimolecular mixture of the two acids. $(\alpha, b)$ Effect of acetate on the rate of disappcarance of propionate from the blood of $B_{12}-$ and $B_{12}+$ sheep. $O$, injection of propionate alone; $x$, injection of propionate plus acetate. $(c, d)$ Effect of propionate on the rate of disappearance of acetate from the blood of $\mathrm{B}_{12}-$ and $\mathrm{B}_{12}+$ sheep. $O$, injection of acetate alone; $x$, injection of acetate plus propionate.

\section{DISCUSSION}

The principal factors that determine the molar proportions of acetic, propionic and butyric acids in rumen fluid are the relative rates of production and absorption. Over the period o- $8 \mathrm{~h}$ after offering the diet used in these experiments the proportions did not vary greatly and were independent of the Co concentration within the rumen between the limits imposed by the Co-deficient diet and that achieved by administra- 
tion of a supplement of I mg Co/d per os (Fig. I). This apparent lack of effect of Co concentration on production and absorption of the volatile fatty acids accords with the observation that digestibility of the fodder is unaffected by the concentration of $\mathrm{Co}$ in the rumen over the range studied (Smith \& Marston, I970b).

Concentrations of volatile acids in the peripheral blood of fed sheep are influenced by a complexity of factors which include the nature of the diet (Egan, 1965; Weston, I966), rates of absorption from the rumen (Gray, 1948; Dobson, I96r; Annison, I965), endogenous production of acids and a series of metabolic reactions. Normally, of the acids produced in the rumen, propionic and butyric are almost completely removed by the liver and rumen epithelium. Oxidation of acetate in liver tissue is less rapid (cf. Armstrong, 1965$)$ and the lower rate of oxidation of acetate coupled with endogenous production of this acid (Annison \& White, I962a) may lead to the presence of considerable amounts of acetic acid in peripheral blood. Formic acid, which may contribute up to $30 \%$ of the total volatile fatty acids in sheep blood (Annison, 1954 and Table )), probably arises from endogenous sources (cf. Salsami, I949; Siekevitz \& Greenberg, 1949; Knox \& Mehler, I950; Annison \& White, I962 b), as little of the small quantity produced in the rumen (Gray, Pilgrim, Rodda \& Weller, 195I; Bensadoun, Paladines \& Reid, I962) is thought to be absorbed (Vercoe \& Blaxter, 1965). There is no evidence of endogenous production of propionate or butyrate (Annison, Brown, Leng, Lindsay \& West, 1967 ).

Of the metabolic reactions influencing concentrations of volatile fatty acids in peripheral blood, probably the most important with respect to the present discussion are the effects which propionate and acetate each have on the other. In some circumstances the concentration of acetate in the blood is reduced as the supply of propionate to the liver is increased (Annison, Leng, Lindsay \&. White, 1963 ) and in others oxidation of acetate is suppressed in the presence of propionate (Pennington, I957; Pennington \& Appleton, 1958; Davis, Brown \& Staubus, 1960; Leng \& Annison, 1963). Again, stimulation of propionate metabolism by acetate has been observed in the tissues of starved sheep (Leng \& Annison, 1963). After feeding, the general tendency under the conditions of the experiments described was for the concentrations of total volatile fatty acids and of formic, acetic and propionic acids to be higher in blood samples of deficient compared with control sheep (Table I). Both the concentrations and proportions of propionic acid were significantly higher in deficient animals than in their controls, although acetic was the predominant acid in each group.

The effect of vitamin $\mathrm{B}_{12}$ deficiency on the metabolism of the volatile fatty acids was tested by comparing the rates at which the individual acids disappeared from the blood following their intravenous injection into starved, pair-fed, vitamin $B_{1^{2}}$-deficient and control sheep. No abnormality was observed in the few deficient sheep examined in clearance tests of formate. Statistical analysis of the results for acetate has shown that, under the conditions of our experiments, acetate was metabolized slightly more slowly by deficient compared with control sheep (Table 2); there was no correlation between impairment in this respect and the degree of deficiency as measured by food intake.

Somers (1969) has reported considerable impairment in the rate of acetate meta- 
bolism in vitamin $B_{12}$-deficient sheep whose food intake was reduced to $200 \mathrm{~g} / \mathrm{d}$. Both the diet of his animals and his method of conducting the clearance tests differed, however, from those used in the experiments described here.

The absence of any significant effect of treatment with aminopterin on the rates at which acetate was metabolized by starved, deficient and control sheep provides no support for the statement made previously (Marston, Allen \& Smith, I96r), that in the very rare instances where acetate metabolism was severely retarded administration of pteroylglutamic acid would restore the animal's capacity to deal with this metabolite. No additional examples of this nature have been observed.

Propionate was metabolized significantly more slowly by vitamin $\mathrm{B}_{12}$-deficient sheep than by control animals, and the rate decreased as the deficiency progressed and food intake fell (Figs. 2, 3). This impairment of propionate metabolism in vitamin $\mathrm{B}_{12^{-}}$ deficient sheep, together with the inhibitory effect that propionate had on the metabolism of acetate (Fig. 4), were probably the most significant factors contributing to the relatively high concentrations of volatile fatty acids found in blood samples of deficient sheep after feeding, and to the delayed rate of acetate metabolism in both fed and starved deficient sheep.

Both pteroylglutamic acid and vitamin $B_{12}$ have been implicated in the metabolism of formate (cf. Stokstad, Webb \& Shah, 1966) and the higher concentrations of formic acid observed in blood samples of deficient compared with pair-fed control animals, after feeding, may result from the dual deficiency or from a real or virtual deficiency of pteroylglutamates; the concentratration of pteroylglutamates, as assayed by Lactobacillus casei, is significantly lower in vitamin $\mathrm{B}_{12}$-deficient than in normal animals (Dawbarn, Hine \& Smith, 1958).

Reports on the chemostatic regulation of appetite in ruminants are conflicting (cf. Balch \& Campling, I962; Holder, 1963). However, depression of appetite following the intravenous injection of acetic or propionic acids, or of sodium acetate (Dowden $\&$ Jacobson, I960), or following the infusion of acetic acid into the rumen (Rook, Balch \& Campling, I960; Montgomery, Schultz \& Baumgardt, I963; Egan, x966) has been recorded. Correlation between progressive failure of appetite, as stores of vitamin $B_{12}$ became depleted, and retardation in the rate at which propionate was metabolized suggested that loss of appetite in deficient sheep depends ultimately on the failure to metabolize propionate at a normal rate; a failure brought about by lack of 5 -deoxyadenosylcobalamin (Marston et al. I96r), the coenzyme essential for the functioning of methylmalonyl-CoA mutase (Cannata, Focesi, Mazumder, Warner \& Ochoa, I965).

The help of Mr C. E. Sleigh and his staff in care of the animals and of Mr W. S. Osborne-White in some of the analytical work is gratefully acknowledged. The diagrams were prepared by courtesy of Mr M. C. Coulls, Division of Soils, CSIRO. Dr E. A. Cornish, Chief of the Division of Mathematical Statistics, CSIRO, kindly provided the statistical analyses of the clearance tests. 


\section{REFERENCES}

Annison, E. F. (1954). Biochem. $\mathcal{F} \cdot \mathbf{5}^{8}, 670$.

Annison, E. F. (1965). In Physiology of Digestion in the Ruminant p. I85 [R. W. Dougherty, editor]. Washington, DC: Butterworths.

Annison, E. F., Brown, R. E., Leng, R. A., Lindsay, D. B. \& West, C. E. (1967). Biochem. F. ro4, r35. Annison, E. F., Leng, R. A., Lindsay, D. B. \& White, R. R. (1963). Biochem. f. 88, 248.

Annison, E. F. \& White, R, R. (I962a). Biochem. Y. 84, 546.

Annison, E. F. \& White, R. R. (I $962 b)$. Biochem. F. 84, 552 .

Armstrong, D. G. (1965). In Physiology of Digestion in the Ruminant p. 272 [R. W. Dougherty, editor]. Washington, DC: Butterworths.

Balch, C. C. \& Campling, R. C. (I962). Nutr. Abstr. Rev. 32, 669.

Bensadoun, A., Paladines, O. L. \& Reid, J. T. (Ig62). F. Dairy Sci. 45, 1203.

Cannata, J. J. B., Focesi, A. Jr, Mazumder, R., Warner, R. C. \& Ochoa, S. (1965). F. biol. Chem. 240, 3249.

Davis, C. L., Brown, R. E. \& Staubus, J. R. (1960). F. Dairy Sci. 43, I783.

Dawbarn, M. C., Hine, D. C. \& Smith, J. (1958). Aust. F. exp. Biol. med. Sci. 36, 54 I.

Dobson, A. (196r). In Digestive Physiology and Nutrition of the Ruminant p. 68 [D. Lewis, editor]. London: Butterworths.

Dowden, D. R. \& Jacobson, D. R. (1960). Nature, Lond. 188, 148.

Egan, A. R. (1965). Aust. 7. agric. Res. 16, 473 .

Egan, A. R. (1966). Aust. F. agric. Res. 17, 741.

Gray, F. V. (1948). F. exp. Biol. 25, 135.

Gray, F. V., Pilgrim, A. F., Rodda, H. J. \& Weller, R. A. (195I). Nature, Lond. 167, 954.

Holder, J. M. (1963). Nature, Lond. 200, ro74.

James, A. T. \& Martin, A. J. P. (1952). Biochem. F. 50, 679.

Jarrett, I. G. (1948). F. Coun. scient. ind. Res. Aust. 21, $31 \mathrm{I}$.

Knox, W. E. \& Mehler, A. H. (1950). J. biol, Chem. 187, 4 I9.

Leng, R. A. \& Annison, E. F. (1963). Biochem. 7. 86, 319.

Marston, H. R. (1970). Br. F. Nutr. 24, 6r 5 .

Marston, H. R. \& Allen, S. H. (1970). Biochem. F. Ir6, 68 I.

Marston, H. R., Allen, S. H. \& Smith, R. M. (1961). Nature, Lond. 19o, 1085.

Montgomery, M. J., Schultz, L. H. \& Baumgardt, B. R. (1963). F. Dairy Sci. 46, 1380.

Pennington, R. J. (1957). Biochem. F. 65, 534.

Pennington, R. J. \& Appleton, J. M. (1958). Biochem. F. 69, 1 I9.

Rook, J. A. F., Balch, C. C. \& Campling, R. C. (1960). Proc. Nutr. Soc. 19, i.

Sakami, W. (1949). F. biol. Chem. 178, 5 19.

Siekevitz, P. \& Greenberg, D. M. (1949). \%. biol. Chem. 18o, 845 .

Smith, R. M. \& Marston, H. R. (r970a). Br. F. Nutr. 24, 857.

Smith, R. M. \& Marston, H. R. (I970b). Br. F. Nutr. 24, 879.

Somers, M. (1969). Aust. F. exp. Biol. med. Sci. 47, 219.

Stokstad, E. L. R., Webb, R. E. \& Shah, E. (r966). F. Nutr. 88, 225.

Vercoe, J. E. \& Blaxter, K. L. (1965). Br. F. Nutr. 19, 523.

Weston, R. H. (1966). Aust. F. agric. Res. 17, 933 . 